\title{
PENATAAN ULANG ADMINISTRASI PUBLIK DI INDONESIA
}

\section{REORGANIZED PUBLIC ADMINISTRATION IN INDONESIA}

\author{
Kristian Widya Wicaksono \\ Jurusan Ilmu Administrasi Publik Universitas Katolik Parahyangan \\ Jl.Ciumbuleuit No. 94 Bandung, Telepon (022) 203357 \\ e-mail:widya_wicaksono@yahoo.com \\ Diterima: 21 Mei 2012, Direvisi: 28 Mei 2012, Disetujui: 31 Mei 2012
}

\begin{abstract}
Abstrak
Hingga saat ini, studi administrasi publik atau yang masih akrab dengan sebutan administrasi negara di Indonesia masih belum ditekuni secara serius di negara ini. Padahal salah satu alternatif jalan keluar dari berbagai macam keterpurukan yang tengah dihadapi bangsa ini ditawarkan melalui pembenahan yang menyeluruh pada konteks administrasi publik. Partai Politik sudah banyak berpartisipasi dalam kancah pengambilan keputusan. Kita juga dapat melihat bagaimana kualifikasi orang yang duduk di kursi kementrian adalah orang-orang yang memiliki reputasi yang baik. Namun pertanyaannya, mengapa perubahan yang diharapkan tidak kunjung berwujud di negara kita? Mengapa varian masalah publik justru semakin berkembang dan bertambah kompleks? Pertanyaan-pertanyaan ini seharusnya segera disadari oleh kita bersama bahwa tanpa reformasi administrasi publik akan sangat sulit mewujudkan perubahan kondisi masyarakat ke arah yang lebih paripurna. Sebaik-baiknya desain kebijakan tanpa didukung aktor implementator yang kompeten dan sistem administrasi publik yang tertata secara sistematik maka hasilnya hanyalah sebatas idealisme di atas kertas.
\end{abstract}

Kata Kunci: administrasi, publik, birokrasi, kebijakan publik \& implementasi

\begin{abstract}
Until today, the study of public administration in Indonesia still not elaborated seriously. Besides alternative solution of the complex problem in Indonesia is the holistic reformation of public administration. Political party is already participated in the arenas of decision making. We also recognize that several people who become the head of the ministry had a good reputation. But the question is, why the expected change in Indonesia still not happened? Why the variations of public problem become increased and more complex? These questions should be realized by us that without public administration reform it will be hard to actualize the change of our society to the right direction. If good design of policy not supported by competent administrator and systematic management of public administration system so the result is only idealism on paper.
\end{abstract}

Keywords: administration, public, bureaucracy, public policy and impementation

\section{PENDAHULUAN}

Wilson (1887) dalam tulisannya The Study of Administration pada Political Science Quarterly menyatakan bahwa tujuan awal pemisahan adminisrasi publik dari ilmu politik adalah untuk menciptakan birokrat yang profesional dalam menyediakan pelayanan publik yang prima tanpa harus membedakan "warna politik" warga Negaranya. Hal ini dimaksudkan agar negara berada pada posisi yang netral sehingga memberikan perlakukan yang adil (equity) kepada publik sebagai agregasi warga negara.

Administrasi dalam dimensi keorganisasian dipahami sebagai birokrasi. Birokrasi pemerintahan dapat ditinjau sebagai officialdom atau kerajaan pejabat, yaitu suatu kerajaan yang raja-rajanya adalah pejabat. Di dalam birokrasi terdapat yurisdiksi, artinya setiap pejabat memiliki official duties. Pejabat birokrasi bekerja pada tatanan hierarki sesuai dengan kompetensi yang dimilikinya. Pola komunikasi yang dibangun di antara sesama pejabat tersebut didasarkan pada dokumen tertulis. Birokrasi pemerintah melakukan pengelolaan pelayanan, menerjemahkan berbagai keputusan politik ke dalam berbagai kebijakan publik, dan melakukan pengelolaan atas pelaksanaan berbagai kebijakan tersebut secara operasional.

Oleh karenanya, birokrasi sebagaimana sifat dan lingkup pekerjaannya, akan menguasai pengetahuan dan informasi serta dukungan sumber daya yang tidak dimiliki aktor lain. Hal ini menyebabkan birokrasi memiliki akses yang luas untuk memformulasikan kebijakan yang tepat secara teknis sehingga mendapat dukungan yang kuat dari civil society dan market. Kondisi empirik inilah yang menyebabkan dikotomi politik-administrasi yang ditawarkan oleh Wilson sulit untuk diwujudkan. Maka dari itu, Frederickson (1997) dalam bukunya The New Concept Of Public Administration menyatakan bahwa konsentrasi penciptaan profesionalitas birokrasi bukan diarahkan pada konsep administrasi melainkan konsep publiknya. Keterlibatan administrasi dalam proses politik untuk 
menghasilkan kebijakan merupakan keniscayaan, namun sistem penyediaan layanan tetap diarahkan untuk meninjau publik secara proporsional yakni sebagai warga negara (citizen). Artinya, birokrasi harus mampu memosisikan warga negara setara baik dari hak maupun kewajibannya.

Stigma yang melekat pada birokrasi di Indonesia adalah mereka para pegawai negeri sipil kerja santai, pulang sebelum jam tutup kantor, selalu mempersulit urusan dan terjebak pada prosedur pelayanan yang berbelit-belit. Ilustrasi tersebut sudah sedemikian melekat dalam benak masyarakat sehingga banyak kalangan yang berasumsi bahwa perbedaan antara dunia preman dengan birokrasi hanya terletak pada pakaian dinas saja.

Keinginan untuk menyaksikan birokrasi yang cerdas, responsif dan bertanggung jawab terhadap proses penyelenggaraan pemerintahan dan pelayanan publik nampaknya sudah mulai surut di kalangan masyarakat. Nampak kejenuhan masyarakat yang telah sedemikian membuncah atas kesempatan yang diberikan kepada birokrat untuk memperbaiki dirinya secara nyata dan menunjukkan perilaku yang kondusif terhadap perubahan sosial. Pemerintah Indonesia saat ini telah mengupayakan agar agenda reformasi birokrasi dapat segera berjalan sebagaimana yang telah diamanatkan dalam UndangUndang Nomor 17 Tahun 2007 tentang Rencana Pembangunan Jangka Panjang Nasional 2005-2025 serta melalui Keputusan Menteri Pembedayaan Aparatur Negara dan Reformasi Birokrasi Nomor: 15/M.PAN/2008 tentang Pedoman Umum Reformasi Birokrasi. Dalam aturan tersebut disampaikan bahwa visi reformasi birokrasi adalah terciptanya tata kelola pemerintahan yang baik tahun 2025 dengan misi diantaranya: (1) Membentuk dan menyempurnakan peraturan perundang-undangan sebagai landasan hukum tata kelola pemerintahan yang baik; (2) Memodernisasi birokrasi pemerintahan dengan optimalisasi pemakaian teknologi informasi dan komunikasi; (3) Mengembangkan budaya, nilai-nilai kerja dan perilaku yang positif; (4) Mengadakan restrukturisasi organisasi (kelembagaan) pemerintahan; (5) Mengadakan relokasi dan meningkatkan kualitas sumber daya manusia termasuk perbaikan sistem remunerasi; (6) Menyederhanakan sistem kerja, prosedur dan mekanisme kerja; dan (7) Mengembangkan mekanisme kontrol yang efektif.

Selanjutnya disampaikan bahwa, tujuan reformasi birokrasi dibagi ke dalam dua skema yakni tujuan umum dan tujuan khusus. Tujuan umumnya adalah Membangun profil dan perilaku aparatur negara yang berintegritas tinggi, produktif, dan mampu memberikan pelayanan yang prima kepada masyarakat. Tujuan khususnya yaitu membangun birokrasi yang bersih, efektif, efisien, transparan dan akuntabel dalam melayani dan memberdayakan masyarakat. Sedangkan sasarannya yakni mengubah pola pikir, budaya kerja dan manajemen pemerintah.
Jauh sebelumnya, Presiden Susilo Bambang Yudhoyono pada masa Kabinet Indonesia Bersatu jilid pertama telah membentuk sebuah lembaga khusus yang dikenal dengan nama Unit Kerja Presiden Pengelolaan Program dan Reformasi (UKP3R) yang salah satu tugasnya melakukan reformasi birokrasi di lingkungan internal pemerintahan. Kemudian, pada tahun 2007 tiga lembaga negara yakni Departemen Keuangan, Mahkamah Agung dan Badan Pemeriksa Keuangan dijadikan pilot project reformasi birokrasi melalui penyesuaian struktur renumerasi bagi pegawai mengikuti beban kerjanya. Dalam perjalananya penyesuaian struktur renumerasi ini diiringi dengan pengawasan yang ketat serta penerapan sanksi yang tegas apabila ditemukan sejumlah pelanggaran.

Akan tetapi, upaya-upaya yang dilakukan oleh pemerintah tersebut belum berdampak banyak terhadap perbaikan kinerja birokrasi. Berdasarkan survei integritas Komisi Pemberantasan Korupsi (KPK) yang diumumkan pada tanggal 22 Desember 2009 yang lalu menyebutkan bahwa masih banyak intitusi pelayanan publik yang belum maksimal dalam memberikan pelayanan publik dan masih melakukan pungutan liar. Hal ini menunjukkan bahwa reformasi birokrasi di Indonesia belum mampu memenuhi tingkat perubahan yang diharapkanoleh masyarakat.

Berlandaskan situasi masalah tersebut, maka tulisan ini mencoba untuk menjelaskan problematika yang menyebabkan upaya melakukan reformasi birokrasi di Indonesia menjadi macet dan mengalami stagnansi. Kemudian, tantangan yang kedepannya harus dihadapi pemerintah dalam pengimplementasian agenda reformasi birokrasi serta menyampaikan sejumlah rekomendasi bagi akselerasi pelaksanaan reformasi birokrasi di Indonesia yang ditinjau dari pendekatan organisasi dan manajemen.

\section{HASIL DAN PEMBAHASAN}

\section{Problematika Reformasi Birokrasi di Indonesia}

Problem pengimplementasian reformasi birokrasi di Indonesia disebabkan oleh sejumlah masalah. Setidaknya kita dapat mengidentifikasi lima kendala utama yang mengganjal dalam proses reformasi birokrasi. Pertama resistensi birokrat terhadap reformasi birokrasi. Hasil survei integritas yang dipublikasikan oleh KPK pada bulan Desember 2009 yang lalu menunjukkan indikasi bahwa proses reformasi birokrasi justru mengalami kendala karena perilaku birokrat yang tidak adaptif terhadap harapan perubahan.

Kedua, menyangkut penerapan model reformasi birokrasi yang terjebak dalam pembenahan struktur renumenasi sebagaimana yang dilaksanakan di Departemen Keuangan RI, MA dan BPK beberapa waktu lalu. Sehingga permasalahan-permasalahan seperti pengembangan sistem informasi peng- 
ambilan keputusan, peningkatan kapabilitas birokrat untuk mengindentifikasi perkembangan kebutuhan masyarakat secara akurat, perbaikan responsivitas birokrasi terhadap aspirasi masyarakat dalam pembangunan serta permasalahan-permasalahan substansial lainnya justru tidak terjawab secara kongkret. Bahkan masalah ini semakin kompleks karena berkolaborasi dengan dorongan-dorongan internal yang lahir dari kalangan aparatur pemerintah seperti keinginan tenaga kontrak dan tenaga honorer untuk segera diangkat menjadi pegawai negeri sipil. Padahal beban belanja tidak langsung dalam anggaran pemerintah untuk membayar gaji pegawai negeri sudah sedemikian besar.

Ketiga, belum munculnya agenda reformasi yang terintegrasi mulai dari Pemerintah Pusat hingga ke Pemerintah Daerah. Sehingga belum ada kesamaan visi dan sinergitas pembenahan birokrasi yang secara kongkret menjadi komitmen bersama untuk merubah praktik penyelenggaraan pemerintahan ke arah yang lebih konstruktif.

Keempat ketidakjelasan landasan dalam proses rekruitmen pegawai. Sebagaimana yang kita ketahui bersama bahwa tahapan seleksi CPNS untuk tenaga Bidan Puskesmas sama saja dengan tahapan seleksi yang dijalani oleh seorang lulusan jurusan Administrasi Negara yang akan ditempatkan di Sekretariat Daerah. Tidak nampak proses seleksi yang secara spesifik dapat dijadikan tolok ukur untuk merekrut pegawai sesuai dengan kebutuhan kompetensi formasi jabatan yang tersedia dalam organisasi pemerintah. Ironisnya perkembangan masalah ini semakin kompleks karena pola pelatihan dan orientasi pegawai negeri belum banyak berubah misalnya materi yang disampaikan selama Diklat Pra-Jabatan tidak terlepas dari doktrin monoloyalitas terhadap Pancasila dan UUD 1945 serta keharusan untuk mengikuti perintah-perintah yang disampaikan atasan. Tidak ada upaya untuk membangun kapabilitas pegawai untuk kritis terhadap pendapat atasan dan meningkatkan kemampuan mereka untuk merumuskan masalah, mengembangkan alternatif pemecahan masalah hingga merekomendasikan pemecahan masalah.

Kelima, promosi yang tidak dilandasi profesionalisme. Meskipun reformasi birokrasi sudah dilaksanakan namun pola promosi pegawai di lingkungan pemerintah masih belum memiliki kejelasan arah. Misalnya saat awal seseorang menjadi pegawai negeri sipil ditempatkan sebagai pegawai kecamatan. Kemudian pegawai ini diberi pelatihan tentang keuangan sesuai dengan rekomendasi camat karena pegawai yang bersangkutan diproyeksikan menjadi tenaga bendahara di kecamatan. Setelah selesai menjalani pelatihan tersebut, pegawai ini lantas diangkat ke Sekretariat Daerah untuk menduduki posisi sekretaris pada Biro Bina Lingkungan Hidup. Sehingga pelatihannya yang lalu tidak dapat dimanfaatkan pada posisinya yang baru. Tidak lama kemudian pada tahun kelima pekerjaannya dia dimutasikan ke Badan Perencanaan Daerah untuk ditempatkan di bagian perencanan pengembangan ekonomi daerah padahal pelatihan yang diberikan kepadanya semasa di Biro Bina Lingkungan Hidup lebih banyak pada bidang lingkungan hidup. Kondisi seperti ini menyebabkan birokrat kita sulit mencapai tingkat profesionalitas yang diharapkan apalagi mengharapkan mereka memiliki pengetahuan yang mendalam atas jabatan yang diembannya.

\section{Tantangan Reformasi Birokrasi di Indonesia}

Reformasi birokrasi dalam pendekatan teori organisasi dapat ditinjau sebagai bentuk pengembangan organisasi (organizational development). Dalam melaksanakan perubahan organisasi maka kita akan menemukan sejumlah tantangan. Untuk konteks Birokrasi publik di Indonesia maka kita dapat mengidentifikasi lima tantangan besar dalam melakukan proses perubahan tersebut. Pertama, mengatasi resistensi perubahan dalam birokrasi yang umumnya disebabkan oleh dua hal yaitu kekhawatiran kehilangan status dalam kekuasaan dan kehilangan sumber-sumber pendapatan siluman. Nampaknya birokrat di Indonesia masih mewarisi tradisi kolonial yakni melakukan pengawasan dan pengendalian terhadap masyarakat. Sehingga manakala terjadi perubahan mereka cenderung bersikap defensif, tertutup dan tidak mau bekerja sama. Prinsipnya yang mereka lindungi adalah status mereka dalam sistem kekuasaan sebab selama ini konstruk birokrasi di Indonesia memang lebih dikondisikan sebagai bagian dari kekuasaan bukan sebagai implementator kebijakan yang berkewajiban melayani kepentingan publik secara berkeadilan. Selain itu, menurut Nordholt dan Van Klinken (2007:11) bahwa pola pemajakan informal serta distribusi pendapatan bottom-up masih mewarnai birokrasi yang bertugas memberikan pelayanan. Para birokrat di Indonesia yang digaji rendah menopang kehidupan mereka dengan sumbersumber pendapatan informal yaitu dengan cara menjual izin-izin dan menarik pajak-pajak pribadi. Sehingga menjadi birokrat di Indonesia belum benarbenar dilandasi keinginan yang kuat untuk memberikan pelayanan yang terbaik bagi masyarakat melainkan hanya sekedar status sosial dan sarana untuk mempertahankan hidup.

Kedua, kepastian mengenai kesinambungan agenda reformasi. Sebagaimana yang kita ketahui bersama bahwa agenda reformasi birokrasi pada prinsipnya sudah ditetapkan dalam Undang-Undang Nomor 17 Tahun 2007 tentang Rencana Pembangunan Jangka Panjang Nasional 2005-2025 dengan maksud untuk menjaga kesinambungan dan konsistensinya. Namun, mekanisme pemilihan kepala pemerintahan secara langsung oleh masyarakat yang bernuansa politis telah membangun keragu-raguan bahwa pemerintahan selanjutnya akan 
tetap mempertahankan agenda reformasi birokrasi tersebut.

Ketiga, kemampuan birokrasi untuk beradaptasi dengan perkembangan teknologi informasi. Saat ini kondisi perkembangan teknologi informasi sudah semakin pesat. Pemerintah pun sudah mulai membuat situs-situs di Internet untuk menginformasikan berbagai macam kebijakan dan program pembangunan kepada masyarakat. Akan tetapi, penerapan electronic government baru sebatas pada pembuatan situs-situs saja, belum melangkah lebih jauh seperti penyelenggaraan pelayanan yang memungkinkan masyarakat untuk dapat mengaksesnya secara terbuka. Pemaparan informasiinformasi di intenet yang dilakukan pemerintah juga masih pada hal-hal yang sifatnya umum belum menukik ke arah informasi-informasi yang strategis seperti informasi anggaran, pembahasan rancangan kebijakan dan lain sebagainya.

Keempat, kemampuan untuk menghadapi lingkungan organisasi yang kompleks dan dinamis. Sebagaimana yang disampaikan oleh Henry (2004:49) bahwa di masa mendatang organisasi pemerintah akan menghadapi sejumlah kenyataan diantaranya adalah batasan organisasi yang semakin memudar, keberadaan pemerintah yang semakin mendatar dan tersebar serta yang terakhir keharusan organisasi pemerintah untuk merubah kapasitas serta skala organisasinya. Berangkat dari prediksi Henry tersebut maka dalam situasi lingkungan yang kompleks dan dinamis, birokrasi dituntut untuk cepat belajar dan beradaptasi sehingga mereka mampu meningkatkan responsivitasnya terhadap kebutuhan masyarakat.

Kelima, mengatasi masalah ketidakpercayaan yang terjadi di antara pemerintah dengan masyarakat. Sebagaimana yang dikemukakan oleh Liddle dalam Gaffar (2006:39) bahwa birokrasi memiliki citra diri yang benevolence yaitu sebagai pengayom, pemurah dan baik hati terhadap rakyatnya. Sedangkan para birokrat mempersepsikan bahwa masyarakat tidak tahu apa-apa sehingga masih harus dididik. Karena birokrasi sudah benevolence maka masyarakat harus patuh, taat dan setia atau obidience kepada pemerintah. Analisa Liddle tersebut memperlihatkan bahwa birokrasi menaruh ketidakpercayaan yang besar kepada masyarakat yang dilayaninya sehingga kerjasama diantara mereka untuk membangun situasi Indonesia yang lebih baik masih cukup sulit untuk diwujudkan.

\section{SIMPULAN}

Problematika dan tantangan reformasi birokrasi sebagaimana yang telah dipaparkan di atas tentunya membutuhkan sejumlah solusi guna mengantarkan reformasi birokrasi menuju tingkat perubahan yang diharapkan. Oleh karenanya, pembahasan dalam tulisan ini selanjutnya mencoba untuk menyampaikan sejumlah pembenahan birokrasi yang ditinjau dari perspektif organisasi dan manajemen.

Pertama, komitmen pimpinan untuk mengawal reformasi birokrasi melalui pelibatan birokrat secara lebih terbuka dalam proses perubahan. Untuk mengatasi resistensi birokrasi terhadap perubahan maka Burke (2005:361) mengemukakan pentingnya kepemimpinan yang partisipatif dalam perubahan. Sebab Burke memberi catatan bahwa keinginan untuk berubah terkadang sudah ada dalam harapan setiap anggota organisasi, namun perbedaan cara untuk mencapai perubahan tersebut seringkali menjadi bagian dari resistensi yang paling sulit untuk dibendung. Oleh karenanya, kepemimpinan yang kuat dan terbuka terhadap keterlibatan anggota organisasi harus muncul dari kalangan birokrat untuk tetap memberikan arah perubahan bagi agenda reformasi birokrasi. Hal ini sejalan dengan tulisan Senge (1994: 297) yang menyatakan bahwa pentingnya untuk berbagi visi agar terbangun pola saling pengertian atasan dan bawahan dalam birokrasi. Sehingga situasi yang dikhawatirkan oleh Ripley dan Franklin (1982:32) bahwa implementasi kebijakan akan menjadi tidak efektif apabila terdapat ketidaksepahaman antara top level bureaucracy (atasan dalam birokrasi) dengan street level bureaucracy dapat segera diatasi. Sebab dukungan bawahan yang tidak optimal baik terhadap perintah atasan maupun terhadap kebijakan akan sangat mempengaruhi tingkat akurasi intepretasi serta pelaksanaan kebijakan di lapangan. Oleh karenanya perlu perubahan pada aspek pusat kekuasaan yang selama ini bertumpu pada pimpinan pemerintah sebab organisasi pemerintah umumnya cenderung sentralistik dengan tingkat formalisasi prosedural yang sulit untuk dinegosiasikan di lapangan. Padahal secara faktual, prosedur seharusnya fleksibel dan adaptif terhadap konteks masyarakat yang dilayaninya. Hal ini juga seolaholah menutup peluang bagi masyarakat untuk memiliki pilihan yang lebih banyak dalam pelayanan publik, artinya dibutuhkan desentralisasi pelayanan dimana level terbawah birokrasi yang bersentuhan langsung dengan masyarakat diberi kewenangan yang lebih banyak dalam merespon kebutuhan masyarakat. Pelibatan sektor privat dalam penyediaan layanan publik juga dapat lebih meringankan beban kerja pemerintah sehingga opsi layanan yang tersedia juga tidak hanya disediakan oleh pemerintah sebagai aktor utama tetapi juga diselenggarakan oleh sektor privat yang selama ini memang memiliki determinasi yang lebih jelas dibandingkan dengan sektor publik.

Kedua, dari segi manajemen dibutuhkan tahapan reformasi birokrasi yang sistematik dan terstruktur. Dimulai dari perencanaan yang akurat, pengembangan sistem yang mendorong terjadinya perubahan perilaku, implementasi sistem baru secara bertanggung jawab hingga pada pengukuran 
perubahan perilaku di kalangan birokrat. Sedangkan dari segi pengawasan dibutuhkan unit pengendalian internal yang kuat dan independen agar reformasi birokrasi tetap berjalan pada jalur yang konsisten dan yang terpenting adalah menciptakan instrumen evaluasi yang ajeg untuk meninjau capaian kinerja dari instansi pemerintah yang mengklaim telah melaksanakan reformasi birokrasi.

Ketiga, pengembangan assessment centre untuk pembenahan sistem dalam birokrasi. Appelbaum, Kay dan Shapiro (2007:51) menyatakan bahwa assessment centre berfungsi bagi perencanaan, implementasi dan evaluasi pada aspek sumber daya manusia dalam sebuah organisasi seperti rekruitmen, seleksi, kompensasi, kegiatan pelatihan dan pengembangan, serta menjadi alat pemantau bagi organisasi dalam melaksanakan penilaian mengenai konsistensi perencanaan dan tingkat capaian sasaran organisasi. Pada sektor publik pembenahan untuk meningkatkan pengelolaan sumber daya manusia memang belum banyak disentuh sehingga tidak terjadi proses staffing yang efektif. Pengembangan assessment centre akan membawa perubahan bagi birokrasi terutama memperbaiki aspek rekruitmen yang selama ini bermasalah, metode promosi yang kurang memperhatikan profesionalisme serta pengembangan materi pendidikan dan pelatihan sehingga lebih sesuai dengan tantangan perubahan sosial. Assessment centre juga dapat membantu untuk memperjelas sistem insentif pada sektor publik yang selama ini kurang mampu mendorong PNS untuk berkarya di daerah pedalaman sehingga pola distribusi pegawai menjadi merata dan tidak berkumpul di kota-kota besar saja.

Keempat, reduksi kepentingan politik dalam birokrasi. Sebagaimana yang disampaikan oleh Ott, Hyde dan Shafritz (1991:181) bahwa perhatian utama dalam administrasi rasional adalah pertumbuhan birokasi. Lebih lanjut ketiga penulis tersebut menguraikan bahwa pertumbuhan berkonsekuensi pada reduksi kepentingan politik dalam birokrasi sehingga mereka dapat bekerja secara optimal. Oleh karenanya, untuk mencapai salah satu sasaran perubahan dalam reformasi birokrasi yakni merubah mindset perlu dilakukan upaya untuk meminimalisir persentuhan antara kepentingan politik dengan birokrasi. Kedepannya birokrasi tidak lagi diizinkan untuk menjadi alat kekuasaan terutama untuk mengawasi dan mengendalikan perilaku publik. Oleh karena itu, tugas kepemimpinan dalam birokrat salah satunya menumbuhkan budaya untuk menempatkan warga negara sebagai pembayar pajak yang harus mendapatkan pelayanan yang prima dari birokrat. Sedangkan pada sisi yan lain birokrat juga perlu berfungsi menjadi fasilitator bagi masyarakat khususnya bagi masyarakat miskin sehingga terjadi pola pemberdayaan masyarakat yang berkelanjutan. Selain itu, reduksi kepentingan politik juga dapat menciptakan jaminan pada kesinambungan agenda reformasi birokrasi meskipun pucuk pemerintahan silih berganti.

Kelima, mengembangkan aplikasi sistem informasi berbasis komputerisasi. Birokrasi pemerintah dapat mengembangkan dukungan terhadap program-program yang akan dijalankannya serta mengomunikasikan berbagai harapan yan hendak dicapai melalui media situs pertemanan sosial seperti Facebook, Twitter, Hi-5 dan lain sebagainya. Misalnya meningkatkan dukungan untuk program hidup sehat dan bersih melalui sosialisasi mencuci tangan sebelum berkaktifitas serta programprogram konstruktif lainnya. Bahkan untuk mensosialisasikan pelayanan yang dapat diakses melalui situs internet sehingga situs pemerintah tidak saja memuat informasi yang umum melainkan informasi-informasi yang lebih strategis dan memungkinkan masyarakat dapat mengakses suatu pelayanan publik.

Keenam, sistem pengawasan dan evaluasi terhadap reformasi birokrasi yang dilakukan oleh lembaga independen. Perlu dilakukan survei berkala yang dilakukan oleh lembaga independen untuk meninjau secara mendetail pelaksanaan reformasi birokrasi pada suatu lembaga pemerintah. Survei integritas yang dilakukan KPK hendaknya tetap dilaksanakan termasuk dengan eksposenya ke hadapan publik agar lembaga yang bersangkutan terus-menerus melakukan pembenahan sehingga dapat mewujudkan tingkat perubahan sesuai dengan harapan publik

\section{DAFTAR PUSTAKA}

Appelbaum, Steven H., Frank Kay and Barbara T. Shapiro. 2007. The Assessment Centre Is Not Dead! How to Keep It Alive and Well dalam Journal of Management Development (8eds)

Burke, Warner. 2005. Memimpin Perubahan Organisasi dalam "Orgaisasi Abad 21: Suatu Hari Semua Organisasi akan Melalui Jalan ini.” Jakarta: PT Indeks Kelompok Gramedia

Gaffar, Afan. 2006. Politik Indonesia: Transisi Menuju Demokrasi (6 eds). Yogyakarta: Pustaka Pelajar

Henry, Nicholas. 2004. Public Administration and Public Affairs (9 eds). New Jersey: Pearson Prentice Hall

Nordholt, Henk Schulte dan Gerry van Klinken. 2007. Politik Lokal di Indonesia. Jakarta: Yayasan Obor Indonesia - KITLV-Jakarta

Ripley, Randall B. and Grace A. Franklin. 1982. Policy Implementation and Bureaucracy. Illinois: The Dorsey Press Homewood

Senge, Peter M. 1994. The Fifth Discipline: The Art and Practice of Learning Organization. New York: Doubleday

Ott, Steven J., Albert C Hyde and Jay M. Shafritz. 1991. Public Management: The Essential Readings. Chicago: Lyceum Books/NelsonHall Publisher 
Wilson, Woddrow (1887) "The Study of Administration," Political Science Quarterly, 2:197-222 